\title{
The Role of Social Media on Establishing Brand Value: A Content Analysis on Banks in Turkey
}

\author{
Zeynep Birce Ergor ${ }^{1} \&$ Elif Akagun Ergin ${ }^{1}$ \\ ${ }^{1}$ Department of Management, Cankaya University, Ankara, Turkey \\ Correspondence: Zeynep Birce Ergor, Department of Management, Cankaya University, Ankara, Turkey. Tel: \\ 90-505-963-1573. E-mail: ergor@ cankaya.edu.tr
}

Received: December 13, 2015

Accepted: January 26, 2016

Online Published: February 25, 2016

doi:10.5539/ijef.v8n3p97

URL: http://dx.doi.org/10.5539/ijef.v8n3p97

\begin{abstract}
There is an increasing use of social media on a global scale and it has been forcing organizations to restructure and adjust their marketing activities. In a relationship-driven economy, the goal of achieving a sustainable competitive advantage makes it crucial to adapt to the ever-changing trends in the market. Social media contributes to this goal since it has a considerable impact on creating and shaping brand value for organizations. The social networks help organizations enhance the development of strong brands not only through promoting their products and services but also providing them the platform to build strong and reliable relationships with their customers. This paper aims to investigate the role of social media on brands by examining the active role of banks on social networks. For this purpose, the "tweets" of the five Turkish banks with the highest brand values in the banking sector have been analyzed by content analysis method. The sample banks are drawn from the Banker's annual Top 500 Banking Brands 2014 report. Brand value is used as the selection criteria of the sample banks and "Twitter" social network is considered as the primary social media outlet. The data is composed of the "tweets" and gathered from the official Twitter accounts of the banks with the highest brand values in Turkey. The "retweets" and the texts sent by other Twitter users are excluded. The findings indicate that the sample banks are active users of social media. These banks do not only use Twitter but also other social networks as well as their official websites. In addition, the paper displays specific purposes the banks have for using social media sites.
\end{abstract}

Keywords: social media, Twitter, Turkish banking sector, brand value, content analysis

\section{Introduction}

The ever increasing popularity of social media lead many organizations to use social networking sites more actively in order to succeed in the global competitive environment. However, there is also an increasing need for updating the understanding of social media and further develop knowledge which suits the imperatives of marketing in social media environments (Hennig-Thurau, Hofacker, \& Bloching, 2013).

According to the Nielsen's "Paid Social Media Advertising Report - 2013", nearly 4 out of every 5 people is an active internet user and they visit social network sites and blogs on a regular basis. In Social Media Report 2012, it is reported that "consumer decisions and behaviors are increasingly driven by the opinions, tastes and preferences of an exponentially larger, global pool of friends, peers and influencers." 2012 statistics reveal that, $70 \%$ of social media users participating at least once a month, hear others experiences, $65 \%$ learn more about brands, products and services, 53\% compliment brands, 50\% express their concerns and complaints about brands and services. These statements show the fact that more than a half of people in the world are using social media consciously and determining the future of today's entities.

The prominent effect of social media on organizations has been researched in various contexts, but most of the recent studies concentrated on its impact on brand management and consumer perceptions. For a company that heavily relies on strong brands and vigorous relationships with its customers, it is critical to analyze the impact of social media. Figures indicate that, especially for services sector, more than $25 \%$ of global consumers tend to purchase services based on social media reviews. The same statistics for financial products and banking services are $47 \%$ on average, suggesting that banks can enhance customer satisfaction and market their services through the active use of social media. When examining the websites of banks, it is seen that banks are already aware of the significant role of social media. Most banks have a special click for "social media services". 
For banking brands, the rapidly growing use of social media among banks necessitates a cost and benefit analysis. Although many studies examine the impact of social networks on services sector, specific research regarding banking sector, especially for Turkey-originated banks, are scarce. To the extent of our knowledge, this is the first attempt putting forth the role of social media on brand value of banks in Turkey. In this regard, the purpose of the study is to explore the use of social media on five banks in Turkey through analyzing their respective Twitter accounts. The sample banks are selected based on their brand values (see Table 1). Content analysis method is employed to find out the mostly commonly used and/or neglected verbs and phrases in banks' social media interaction. The paper is organized as follows, previous studies will be reviewed briefly in the literature review, then in the next section the data and methodology will be introduced. The study will be concluded with a discussion of the findings, limitations of the research and avenues for future research.

\section{Literature Review}

Social media is defined as "the interaction among people in which they create and exchange information and ideas in virtual networks". Another definition is given by Kaplan \& Haenlein (2010) as "social media is a group of internet-based applications that build on the ideological and technological foundations of Web 2.0 and it allows the creation and exchange of user-generated content"( See-To \& Ho, 2014). Integrating both descriptions, we can define social media as "the platform of creating and exchanging the user-generated information."

Through social media, and with the help of technology, it is possible to access and share new information instantly with people around the world. For this reason, social media is a great tool for transferring "likes" as well as "dislikes". Research shows that people tend to pay attention to other people's experiences with a product or service and this shapes their attitudes towards brands. Any positive or negative statements made by potential, actual or former customers about a product or a company are considered as an important source of information. These statements are also reported to have a considerable effect on consumers' trust for a firm and products, thus affecting the consumer purchase intentions (Chu \& Choi, 2011; See-To \& Ho, 2014). It has been observed that when the number of positive statements about a product or service is high in social networks, then consumers will be more likely to generate positive expectations about the product or service. These kind of positive interpretations also enhance consumers' trust towards the product or services. However, when there are a huge number of negative statements about a company or a product/service, this damages consumers' trust and reduces their purchase intentions (See-To \& Ho, 2014). Thus, it can be concluded that the social media can either add to or take away from the brand value of a product and service.

One of the main challenges for marketers has been to see how their efforts can pay off and how their social media activities can influence important brand related variables (Hoffman \& Fodor, 2010). In a study that examine the impact of using social media on organizations, Parveen (2012) reports that companies actively use social media with the purposes of advertising, marketing, communicating and building relationships with customers and branding. He also emphasizes the benefits of using social media such as cost reduction, revenue generation, innovation, improving customer relationship, enhancing brand reputation, provide value, relationship and brand equity. Schivinski and Dabrowski (2014) also suggest that user-generated social media communication leads to a positive impact on brand equity and attitude while firm generated social media communication has a positive effect on brand attitude. They also conclude that increased brand equity and brand attitude improve purchase intentions. In another study, Erdogmus and Cicek (2012) examine the impact of social media on brand loyalty in Turkey and concluded that a consumer's brand loyalty is significantly affected by the activities in social media. They report that lucrative campaigns offered by companies on social media are key factors for building brand loyalty. Finally, Laroche, Habibi, and Richard (2013) show that social media has a significant impact on building relationships among customers, products, and brands which help to generate brand trust and brand loyalty. They conclude that, the relationships between customer-product, customer-brand and customer-company have a direct and positive impact on brand trust. All of these findings indicate that social media has a major role in creating/ shaping brand value in terms of brand trust, brand loyalty, consumer attitude, and brand reputation.

\section{Data and Methodology}

The sample banks in the study are drawn from the Banker's annual Top 500 Banking Brands 2014 report. Brand value is used as the main selection criteria for the sample banks and "Twitter" social network is considered as the social media platform. The data are composed of the "tweets" and gathered from the official Twitter accounts of the banks having the highest brand values in Turkey (see Table 1). The sample period covers the months of March, April and May, 2014. The "retweets" and the texts sent by other Twitter users are excluded. The overall data are analyzed by content analysis methodology. The main reason of preferring this method relies on the fact 
that it is the technique that has been widely accepted and utilized in the analyses of the contents in a text or a document (Opoku, Abratt, \& Pitt, 2006). In order to examine the role of social media on brand value, we attempt to answer the following research question (RQ):

RQ: How do banking brands in Turkey use social media in order to create brand value?

Table 1. Top 5 valuable banking brands of Turkey

\begin{tabular}{lcccc}
\hline & Brand Value & Brand Value & Rank & Rank \\
Bank/Brand & 2014 (\$million) & 2013 (\$million) & 2014 & 2013 \\
\hline AKBANK & 1983 & 2121 & 96 & 86 \\
IS BANK & 1893 & 2061 & 98 & 89 \\
GARANTI BANK & 1364 & 1579 & 122 & 110 \\
YAPI KREDI BANK & 1099 & 1117 & 142 & 135 \\
ZIRAAT BANK & 968 & $\mathrm{n} / \mathrm{a}$ & 152 & $\mathrm{n} / \mathrm{a}$ \\
\hline
\end{tabular}

Source: "Top 500 Banking Brands 2014 (Worldwide)" http:// www.thebanker.com

\section{Results}

Table 2 presents the number of tweets, followers, photos/videos, the accounts followed and the date of registration to Twitter for each bank. It is observed that, the earliest and the latest memberships belong to Garanti Bank and Ziraat Bank, respectively. Although Garanti is the first-mover for the use of Twitter among the banks, it is surprising that the number of its tweets is lower than the ones sent by Is Bankasi, Akbank and Yapi Kredi Bank. Even so, Garanti has the highest number of followers and uploaded photos/videos in addition to followings.

It is seen that Akbank, as the highest brand-valued bank, is in second place with 4547 tweets. Akbank is also in fourth place with its 43,630 followers. Is Bankasi is the leader among the banks in terms of the number of tweeted texts. Moreover, it has the second highest number of followers. As for the latest participant of Twitter, Yapi Kredi seems to be an active user of Twitter with its 3892 tweets. It also seems to have performed well in drawing attention of the other Twitter users, especially when compared to Ziraat Bank and Akbank. It is important to note that even though both Ziraat Bank and Akbank registered with Twitter before Yapı Kredi, the number of their followers remain much less than that of Yapi Kredi.

The Twitter outlook of the banking brands are given in numerical values. The bank-specific findings are presented next in detail.

Table 2. Twitter outlook of the top banking brands of Turkey

\begin{tabular}{lccccc}
\hline Bank/Brand & Tweets & Photo/Video & Following & Followers & Registration \\
\hline IS BANKASI & 7896 & 104 & 4 & 57582 & July, 2009 \\
AKBANK & 4547 & 140 & 7 & 43630 & August, 2010 \\
YAPI KREDI BANK & 3892 & 73 & 8 & 44909 & July, 2011 \\
GARANTI BANK & 2073 & 241 & 505 & 104295 & April, 2008 \\
ZIRAAT BANK & 855 & 163 & 3 & 26567 & November, 2010 \\
\hline
\end{tabular}

\subsection{Is Bankasi}

The twitter messages of Is Bankasi consist of the activities and articles for female entrepreneurs, job vacancy advertisements, congratulatory messages and new branch (subsidiary) announcements. It introduces its nationwide new branches frequently with a "now at your service" texts. The congratulatory texts include both national and global celebrations such as "Happy Independence Day, Happy Mother's Day, Happy Children's Day". The bank also features disaster mourning announcements such as the loss of 301 miners in Soma mine disaster that happened in May 13, 2014. In one of those announcements, they declared their decision of deferring the individual loan repayments of victims and deleting the credit debts of those who lost their lives. The rest of the texts are related to their corporate social responsibility activities such as organizations for the education of poor children. Furthermore, the bank uses Twitter for promoting its credit campaigns, pension plans, bank account services, and art organizations through directing to its Facebook account and/or official website. Finally, 
it emphasizes words and phrases such as "trust", "advantageous", "Is Bankasi is by your side”, and "a strong step to professional life”.

\subsection{Akbank}

It is observed that Akbank mostly features bank-specific individual messages from executives of its departments. The second most common tweeted texts belong to the announcements of the organizations with Akbank's sponsorships. For instance, the bank promotes the campaigns of Akbank Sanat Dostu (Art Companion) by offering free tickets to ballet performances, musicals, and film festivals. The bank also fortifies its Twitter account through organizing web-based contests. In addition to these, Akbank supports its brand by announcing that it has been selected as the "strongest social brand" in finance by reputable sources like Ekonomist and Brandwatch. It is easy to notice that several tweets highlighting the "strongest social brand" statement are sent consequently. The bank also shares congratulatory texts such as National Sovereignty Day, World Foursquare Day, and World Women's Day. The memorial texts are sent for Soma victims, Sakip Sabanc1 (the son of the founder of Akbank who died in April 10, 2004) and Martyrs of the Dardanelles. The announcements of deferring the loan repayments of victims and deleting the debts of those who lost their lives in Soma mining disaster are also present. Furthermore, the bank directs its followers to its official website and Facebook account in order to inform them of its financial services and campaigns. The mostly mentioned words and phrases among Akbank's tweets consist of "strong", "support”, “campaign”, "thanks", "film”, "festival”, "syndicated loan”, "contest”, "prize”, "in his speech", "grew/growth”, "Akbank's support”, "strongest brand”, "strong capital”, "customized products for our customers", "heart beat rates”, and "mobile banking”.

\subsection{Yapi Kredi}

Yapi Kredi's tweets are mainly composed of the promotional contest questions and the direct messages sent to the winners of the campaigns it mounts. The texted words include "Congratulations! You win! Please share your phone number with us" and "You are the champion! Waiting for your phone number and contact information through DM (direct message) to send your gift" It is recognized that the campaigns are designed to promote the events that are sponsored by Yapi Kredi. Event-related questions are asked in a sequence and free tickets to the events are offered as prizes. Among the tweets, there are congratulatory and mourning texts, again for the May 19th, April the 23rd, Mother's Day, Women's Day, and Soma victims, Martyrs of the Dardanelles. The rest of the tweets that are related to financial services and other promotions are limited, most of them direct users to Yapi Kredi's official website. Mostly used words and phrases are: "congratulations", "please”, "DM", "won a ticket to concert", "contest", "you are the champion", "keep following”. Other statements that draw attention are "here, women are always precious" and "we missed you a lot (including with a smiley)"

\subsection{Garanti}

Garanti appears to be the one tweeted the most for the last three months among the rest of the banks. Its tweets are heavily based on the promotional briefing of its campaigns and services. Almost all of them are directed to the official website, Facebook and Instagram account of Garanti. Garanti's congratulatory and mourning texts differ from those of others'. The celebration or sorrow messages are essentially written within or next to another statement. For example, instead of Happy May 19th, Garanti texted "Happy new May 19th to the youth of our future's guarantee, we commemorate Mustafa Kemal Ataturk with respect". Like the other banks, Garanti decided to defer and waive the debts of those who get hurt and lost their lives in Soma, and announce it to public through Twitter. Different from others, Garanti posted celebration tweets for the Insurance Week, Hurdle Week, and International Jazz Day. It is observed that, most of the tweets are related to the bank's promotions, especially in celebration days. Thus, Garanti seems to perform well in taking the advantage of special days for promoting its product and services through Twitter. The tweets also include the bank specific individual messages of executives and experts in other fields such as sociologist, ecologist, and university lecturers. Moreover, the tweets also include the bank specific job vacancy announcements for different positions. It is also observed that the bank features tweets for its corporate responsibility activities organized for LOSEV and hurdled/impaired children, for instance. It also gives place to texts related to women entrepreneurs and SMEs. The mostly mentioned words and phrases are as follows: "insurance", "e-term accounts", "interest rates", "credits", "gain money", "thanks" "women entrepreneurs", "selfie”, “campaign”, "Bonus”, "gain more”, "iGaranti” and "internet branch (online banking)".

\subsection{Ziraat Bankasi}

As the latest member, Ziraat Bankasi uses Twitter mostly to announce its daily economic-financial bulletin and TOKİ projects that will be offered for sale in various cities. The limited number of tweets is composed of congratulatory, memorial, informative and promotional texts. In addition to Mother's Day, Women's Day, May 
the 19th, and April the 23rd, Ziraat Bank celebrated the World Farmer's Day, Medicine Day. Sorrowful messages for victims in Soma disaster and Martyrs of the Dardanelles also takes place. Mostly used words and phrases by Ziraat Bank are: "daily financial and economic bulletin", "TOKI will be offered for sale projects", "all our branches are empowered for sales of projects", and "syndicated loan". Finally, a noteworthy statement in one of tweets appeared to be "An increasing and winning account for our Loyal Customers: Loyal Exchange Account".

\section{Conclusion}

Social media has become a powerful communication tool for many brands in various industries. Social media is the perfect platform for a brand to communicate its expertise in a given industry, and do so by providing great content that people will share with others. For this specific study, the goal is to explore and emphasize the role of social media on building brand value in the banking sector in Turkey. In this context, our findings provide insights to the question of "How do banking brands in Turkey use social media in order to create brand value?" The study is unique since no similar study has been carried out so far in Turkey.

A content analysis is conducted on the respective Twitter accounts of five banks with the highest brand values in Turkey. The findings indicate that all of the sample banks are active users of social media. They not only use Twitter but also other social network platforms such as Facebook and Linkedin in addition to their official websites. Considering the common characteristics of the banks' posted tweets, it can be concluded that:

The top 5 banking brands in Turkey use social media for the purposes of:

- Promoting their products, services, campaigns, brands and social responsibility activities. Socially responsible brands often gain more respect and popularity because their customers know they aren't just about profits, but also giving back to their communities or the society around them.

- Creating social relationships with their customers in an online environment that can be transferred offline.

- Building brand trust. Trust is a fundamental building block of any brand. Social media helps build that trust.

- Enhancing brand positioning, brand value and customer loyalty.

- Expressing their celebrations for national/global holidays and sorrows for disasters.

\section{Limitations and Recommendations for Further Research}

Although our research contributes to the literature in the field of social media use of banking brands in terms of brand value enhancement, it is subject to several limitations. First, our sample size and sample period are narrow. Second, the "retweeted" texts of the banks, public responses to the tweets and the conversations between the banks and their customers are not included in the research. Finally, the findings of our content analysis are mainly based on paraphrasing. Further research attempts can replicate our study by increasing the number of sample banks and sample period. It would be a fruitful action to study with the data including the "retweets", responses and conversations. And lastly, conducting several focus group interviews would be very useful to corroborate the concluding remarks of this study. A similar study could be carried out by comparing urban vs rural consumers of the banks to determine whether there are any significant differences in their perceptions.

\section{References}

Chu, S. C., \& Choi, S. M. (2011). Electronic word-of-mouth in social networking sites: A cross-cultural study of the United States and China. Journal of Global Marketing, 24(3), 263-281. http://dx.doi.org/10.1080/08911762.2011.592461

Erdogmus, İ. E., \& Cicek, M. (2012). The impact of social media marketing on brand loyalty. Procedia-Social and Behavioral Sciences, 58, 1353-1360. http://dx.doi.org/10.1016/j.sbspro.2012.09.1119

Hennig-Thurau, T., Hofacker, C. F., \& Bloching, B. (2013). Marketing the pinball way: Understanding how social media change the generation of value for consumers and companies. Journal of Interactive Marketing, 27(4), 237-241. http://dx.doi.org/10.1016/j.intmar.2013.09.005

Hoffman, D. L., \& Fodor, M. (2010). Can you measure the ROI of your social media marketing? MIT Sloan Management Review, 52(1), 41-49.

Kaplan, A. M., \& Haenlein, M. (2010). Users of the world, unite! The challenges and opportunities of Social Media. Business Horizons, 53(1), 59-68. http://dx.doi.org/10.1016/j.bushor.2009.09.003

Laroche, M., Habibi, M. R., \& Richard, M. O. (2013). To be or not to be in social media: How brand loyalty is affected by social media? International Journal of Information Management, 33(1), 76-82. http://dx.doi.org/10.1016/j.ijinfomgt.2012.07.003 
Nielsen Paid Social Media Advertising Report - 2013. Retrieved from http://www.nielsen.com/us/en/reports/2013/the-paid-social-media-advertising-report-2013.html

Nielsen Social $\quad$ Media $\quad$ Report $\quad-\quad 2012 . \quad$ Retrieved from http://www.nielsen.com/us/en/newswire/2012/social-media-report-2012-social-media-comes-of-age.html

Opoku, R., Abratt, R., \& Pitt, L. (2006). Communicating brand personality: Are the websites doing the talking for the top South African business schools? Journal of Brand Management, 14(1), 20-39. http://dx.doi.org/10.1057/palgrave.bm.2550052

Parveen, F. (2012). Impact Of Social Media Usage On Organizations. In PACIS (p. 192).

Schivinski, B., \& Dabrowski, D. (2014). The effect of social media communication on consumer perceptions of brands. Journal of Marketing Communications, (ahead-of-print), 1-26. http://dx.doi.org/10.1080/13527266.2013.871323

See-To, E. W., \& Ho, K. K. (2014). Value co-creation and purchase intention in social network sites: The role of electronic Word-of-Mouth and trust-A theoretical analysis. Computers in Human Behavior, 31, 182-189. http://dx.doi.org/10.1016/j.chb.2013.10.013

The Top 500 Banking Brands Report 2014. Retrieved from http://www.thebanker.com/Banker-Data/Banker-Rankings/The-Top-500-Banking-Brands-2014

\section{Copyrights}

Copyright for this article is retained by the author(s), with first publication rights granted to the journal.

This is an open-access article distributed under the terms and conditions of the Creative Commons Attribution license (http://creativecommons.org/licenses/by/3.0/). 